Critical Studies in Improvisation / Études critiques en improvisation, Vol. 14, Nos. 2-3

\title{
Better Ways of Sharing
}

\section{Dave Clark}

The onset of the pandemic saw all of my live performance work, my recording work, and my income from teaching come to a complete halt. I pivoted to offering lessons online and, over the past eight months or so, have gathered a small group of online students. It was valuable to learn a new mode of teaching that I will use from here on out as an adjunct to in-person lessons.

I performed solo shows via Instagram Live, the National Arts Centre's \#CanadaPerforms series, musictogether.ca, and Side Door Access. Playing online was exhilarating, as it was new to me. These experiences were valuable both as cathartic musical moments and as lessons that have helped me to learn how to present my music on a different platform. Because I was alone, I felt free to play with the events and curate them in any form I liked. It was a deeply emotional experience as well, because I felt the crush of the pandemic really affecting my psyche in a huge way. With all my work and outlets gone, I was in the midst of an existential crisis. (I know this to be true for so many of my musician friends, too.) This little online window, then, became a place to pour energy into for the first time. I played these online concerts for a spell, until the murder of George Floyd. At that time, I took my voice off of Instagram to make space for those who needed to be heard. I'll come back to Instagram in the new year. The time for introspection since then has been good for me.

In May of 2020, I wrote the accompanying open letter to the Society of Composers, Authors and Music Publishers of Canada (SOCAN) in response to their new online performance remuneration initiative. It required a performer to draw 100 audience members to each online performance in order to be eligible to collect a SOCAN payout of $\$ 150$. I asked them to adjust the minimum number of audience members to 50 people in order to make it possible for working musicians to share in the funds being dispersed by SOCAN. I also suggested a simple pro-rated fee structure, which seemed fair in light of artists having to establish themselves online in difficult circumstances. SOCAN responded with an auto-generated email saying they would respond in one to two days. I have no record of that promised response.

There was also a small, bittersweet window in the summer when I gathered in the park near my place with a few friends to play music at a safe distance. It was so sweet to see friends and to connect musically and socially. It was a lifeline to sanity. It felt so soothing and free to be in the sunlight and amongst the trees, taking in the shadows and the motion of the leaves in the breeze. It was the highlight of my week when it happened. The music resonated deeply with me and my friends. There was a lot of laughter, and there were tears too. It was also bitter to know that we couldn't hug; that we wouldn't be playing our gigs from the "old days," as it were; and that we didn't want crowds to gather on our behalf, because we didn't want to be responsible for folks gathering in unsafe ways. This window was short and fraught with worry about public health concerns, and so it was closed again. I believe that was for the best, in relation to COVID-19.

All throughout the pandemic, I have worked back and forth online with friends trading tracks, crafting songs, building recordings, and upping my mixing and mastering game. This, likewise, has been good for my artistic expression and for my mental health. I've tried to keep up with working on my craft. I am, at the time of this writing in fall 2020 , looking into soundjack.eu as it offers peer-to-peer, low-latency, online music-making possibilities.

I've found this time isolating and challenging for my artistry and mental health. I love making 
music with friends, making friends through music, and sharing it outward. I deeply miss it all.

\section{Open Letter}

\section{SOCAN Friends,}

Thanks for looking out for Canadian musicians through this unprecedented time by setting up payment for online gigs.

My name is Dave Clark. I have been gigging for 40 years locally, nationally, and internationally.

Like a lot of my peers, I play everywhere from small clubs to major festival and concert stages internationally. That said, most players (when you aren't a major name and are off the road) tend to play small clubs to audiences ranging from 20 people to about 70 people on a good night. The door for those gigs can generally average about $\$ 10$, so the gigs are claimable.

Now, as we transition to online, it's unlikely that all of us who are building this new paradigm can pull 100 people straight out of the gate. For some, never.

I have gathered up to 90 people, but not on average. 50 would be more likely. That's a great crowd in a small club playing solo. I'd be cracking a good chunk of change for myself on that, even on a jug pass gig.

I feel that to make 100 audience members the payout mark for SOCAN artists during these times is asking too much and excludes a great deal of the artists who are the absolute backbone of the Canadian music industry.

Perhaps a redraw on that and starting the payout at 50 people would be fairer and more possible. Even a pro-rated system of $\$ 100$ at 50 audience members and $\$ 150$ for an audience of 100 and above would be much more equitable.

Please share and consider this with the folks at SOCAN.

Thanks for all of your hard work, kindness, and consideration.

Be well.

Take care.

Peace

dc 